\title{
Protection of Impact Electromagnetic Radiation on Public Health and Environment, Indonesia
}

\author{
Muhamad Mujahidin ${ }^{1 *}$, Tonny Suhendra ${ }^{1}$, Sapta Nugraha $^{1}$, Rusfa Rusfa $^{1}$, Bunga Paramita $^{2}$ \\ ${ }^{1}$ Electrical Engineering Faculty, Raja Ali Haji Maritime University, Tanjungpinang 29411, Indonesia \\ ${ }^{2}$ Economic Faculty, Raja Ali Haji Maritime University, Tanjungpinang 29411, Indonesia \\ Corresponding Author: mujahidin@umrah.ac.id
}

\begin{abstract}
A penetration of SUTET trajectory in residential areas, causing public health problems and environmental problems. Development of the electrical energy sector, regulation the increasing electricity demand. Distribution electricity from inter-GI generating centers requires SUTET in the air with a voltage above $245 \mathrm{kV}$. The community assesses health impact that operates mostly with the voltage of $500 \mathrm{kV}$, $>1000 \mathrm{~mA} / \mathrm{m}^{2}$, can cause heart problems, extrasystole rhythms, and ventricular fibrillation Electrical sensitivity. A simple method and integrating the divergence shift flux density a radiation point, a method proposed from Strokes theorem relates the closed line integral vector field to curl surface integral and divergence theorem which relates the surface integral a closed vector field to integral volume and divergence vector field, this experiment electric field produced by the line charge is directed radially away from the line charge, so the direction lines electric field(E), and equipotential surfaces perpendicular to each other. This study is a collection of symptoms hypersensitivity, comprehensively, and a potential difference between two points in the electric field, which has the performance of charge unity in responding to charge from both points the area, the solution is environmental-based management. Ionizing radiation is the dispersion or emission energy when through a medium, absorption process occurs, and radiation energy beam does not induce, results in vector potential having magnitude is inversely proportional the radial distance from the element which is similar to inverse distance dependence scalar potential. In conclusion, take steps to empower the community for residents in the area SUTET.
\end{abstract}

\section{Introduction}

The spectrum of electromagnetic waves that we know cover a wide frequency range. Radio waves, television signals, radar rays, invisible light, $\mathrm{x}$-rays, and gamma rays are the examples of electromagnetic waves. In a vacuum, these waves all travel at the same speed, 3 x $108 \mathrm{~m} / \mathrm{s}$. Electromagnetic sources are everywhere. The sun, stars, lights, and tornadoes are natural sources of electromagnetic waves. The artificial electromagnetic sources such as nuclear explosions, electrical circuits with vacuum tubes or transistors, microwave diodes, radio antenna lasers. Human body will be illuminated by various frequencies of complex magnetic waves. Level of exposure to electromagnetic waves of multiple frequencies changes significantly in line with technological developments, which raises concerns that exposure to these electromagnetic waves, can adversely affect human physical health. There is a possibility that the disturbance is electrical sensitivity. Where physiological disorder with neurological signs and symptoms as well as. Sensitivity, in the form of various symptoms and complaints. This interference is generally caused by electromagnetic radiation originating from high, or extra high voltage power lines, electronic equipment at home, in the office or industry. Including cell phones (cell phones) and microwave ovens, it turned out to have very potential to cause various complaints. Many people claim that the electromagnetic waves emitted by power tools can harm the health of users and those who stand around them. This assumption is justified by experts in the field of telecommunications, but there are also objections by several parties who deny otherwise. Based on the above, an outline of electromagnetic waves and their effects on human health will be explained. Indication is that exposure to electromagnetic fields originating from SUTET $500 \mathrm{kV}$ is at risk of causing health problems for living things, namely a set of hypersensitivity symptoms known as electrical sensitivity. Based on medical understanding, high-frequency source radiation waves are more dangerous than low-frequency sources. The purpose of this study is to analyze the effects caused by electromagnetic wave radiation that causes human and environmental health problems. Formulation of the problem in the research, how to overcome the induction due to the intensity of the electromagnetic field on public health and the environment. A simple method of modeling and integrating the divergence of the shift flux density of a radiation point, the method proposed from the Strokes theorem is to relate the closed line integral of the vector field to the Curl surface integral and the vector field and the Divergence theorem which relates the surface integral of a closed vector field to volume integral and the divergence of the vector field. Experiment shows that the electric field produced by the 
line charge is directed radially away from the line charge, so that the direction lines of the electric field (E) and equipotential surfaces are perpendicular to each other. in this study is a collection of symptoms (syndrome) of hypersensitivity, comprehensively, as well as the potential difference between two points in an electric field, which has the performance of charge unity in responding to a charge from both points of the area, the solution is environmental-based management. Ionizing radiation is the dispersion or emission of energy when through a medium, an absorption process occurs, and the radiation energy beam does not induce and the ionization process results in a vector potential having a magnitude that is inversely proportional to the radial distance from the element which is similar to the inverse distance dependence of the scalar potential. Electricity produced by a point charge parallel to the current part. In conclusion, take steps to empower the community (community development) for residents in the area and around SUTET.

\section{Literature review}

Rule No.15 1985 concerning Electricity, Regulation Minister of Mines and Energy No. 01.P/47/MPE/1992 Regarding SUTT Free Space and SUTET For Electricity Distribution and Decree of the Minister of Mines and Energy No. 975 K/47/MPE/1999 Regarding Regulation Changes Minister of Mines and Energy No. 01.P/47/M.PE/1992 Regarding SUTT Free Space and SUTET For Electricity Distribution. Other than that, $500 \mathrm{kV}$ SUTET construction has also been completed have the Indonesian National Standard (SNI), namely SNI 04.6918-2002 regarding free space and distance free minimum SUTT and SUTET and SNI 04.69502003 concerning Terrain Threshold Value Electric and Magnetic Fields SUTT and SUTET. The rules indicate distance or space which is safe from the influence of electric and magnetic fields magnets. So people know the area that is safe for activity. This safe distance is measured based on the high voltage, medium, and low voltage networks (JTM/JTR). In this area, a simple formula can be used, i.e., $1 \mathrm{kV}=1 \mathrm{~cm}$. This means that if the voltage in the wired network of $20 \mathrm{kV}$, then the safe distance is $20 \mathrm{~cm}$ or $0.2 \mathrm{~m}$. For SUTT and SUTET transmission, the rule of safe vertical space (C) is for stress $70 \mathrm{kV}$ is $4.5 \mathrm{~m}$, for $150 \mathrm{kV}$ is $5.5 \mathrm{~m}$, for $275 \mathrm{kV}$ it is $7.5 \mathrm{~m}$, and for $500 \mathrm{kV}$ it is $9.5 \mathrm{~m}$. While the safe horizontal distance from axle/axis of tower (D) is for voltage $70 \mathrm{kV}$ is $7 \mathrm{~m}$, for $150 \mathrm{kV}$ is $10 \mathrm{~m}$, for $275 \mathrm{kV}$ is $13 \mathrm{~m}$, and for $500 \mathrm{kV}$ is $17 \mathrm{~m}$. PLN itself has made a guardrail to maintain free space and safe distance as well as periodically carry out field strength measurements electricity using electromagnetic tools Field Meters. According to the World Health Organization (WHO) Organization) electric field strength threshold and a magnetic field that does not harm to the human body at $5 \mathrm{kV} / \mathrm{m}$ for the electric field and $0.1 \mathrm{~m}$ Tesla for the magnetic field. From the measurement results of what PLN has done so far, the field strength electricity and magnetism in various areas of SUTT and SUTET in Indonesia are still below the threshold. In addition to periodic measurements, PLN also provides counseling about safe distance rules to society. This training is aimed at giving a correct understanding of the influence of electric and magnetic fields so that people who live around the means of transmission. This have the right perception and sense of security to live in the vicinity. This counseling is usually given by PLN at the beginning of the operation of SUTT and SUTET, but this counseling can also be given on another occasion if the community need it(I.B. Alit Swamardika, 2009)

\subsection{Stokes' and Divergence Theorem}

variable $F=M \mathrm{i}+\mathrm{Nj}+\mathrm{Pk}$ is a vector field with $\mathrm{M}, \mathrm{N}$, and $\mathrm{P}$ having continuous first-order partial derivatives at $\mathrm{S}$ and the limit is $\delta \mathrm{S}$, then,

$$
\oint_{\delta s} F . T d s=\iint_{s}(\operatorname{curl} F . n d s
$$

Surface $S$ in the magnetic field region is integrated on the smaller surface, $\Delta \mathrm{S}_{1}, \Delta \mathrm{S}_{2}, \Delta \mathrm{S}_{3}$, and is bounded by the electromagnetic field lines $\mathrm{C}_{1}, \mathrm{C}_{2}, \mathrm{C}_{3}$, So, the current density of the displacement that occurs is

$$
\nabla \times \mathrm{H}=\mathrm{J}
$$

A vector quantity states that a point in a current region is affected by the current density shift, every reduction in the surface of the electromagnetic field is indicated by the number of very small surfaces and tends to infinity, then,

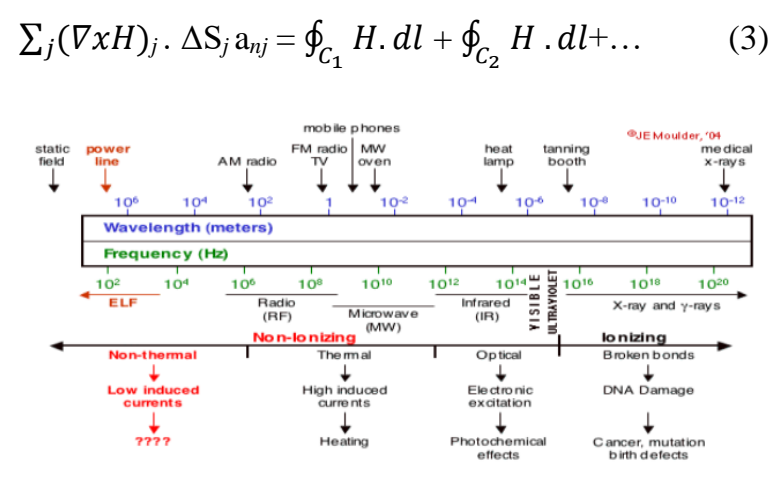

Fig. 1. Electromagnetic Spectrum (Anies, 2006)

Symptom is related to many factors. Examples of disease blood cancer. It can be related to the factor genetic, nutritional, behavioral, or other harmful substances In the environment. It's very hard to prove the cause-and-effect relationship between the SUTET effect and human health because humans can't use as an experimental research object (observed). In addition to being against basic principles of medical morals and ethics, it can also violate human rights. Based on research done so far, the health problems that people often complain about, such as dizziness, pain muscles, itching of the skin, shortness of breath, insomnia, palpitations, visual disturbances, etc., are psychosomatic disorder that is subjective. Furthermore, Radiation Electromagnetism is a physical environmental factor that needs to be considered. 
Therefore, health problems are not just a disease. Various complaints or physical symptoms experienced by a person are forms of health problems. Even different a phenomenon that causes a person to feel no safe and uncomfortable, even feel anxious, actually not in good health or have health problems (Anies, 2006)

\section{Result and Discussion}

Show distance or space which is safe from the influence of electric and magnetic fields magnets. So people know the area that is safe for activity. This safe distance is measured based on the high voltage, for medium and low voltage networks (JTM/JTR). In this area, a simple formula can be used i.e., $1 \mathrm{kV}=1 \mathrm{~cm}$. This means that if the voltage in the wired network of $20 \mathrm{kV}$, then the safe distance is $20 \mathrm{~cm}$ or $0.2 \mathrm{~m}$. For SUTT and SUTET transmission, the rule of safe vertical distance (C) is for stress $70 \mathrm{kV}$ is $4.5 \mathrm{~m}$, for $150 \mathrm{kV}$ is $5.5 \mathrm{~m}$, for $275 \mathrm{kV}$ it is $7.5 \mathrm{~m}$, and for $500 \mathrm{kV}$ it is $9.5 \mathrm{~m}$. While the safe horizontal distance from axle/axis of the tower (D) is for voltage $70 \mathrm{kV}$ is $7 \mathrm{~m}$, for $150 \mathrm{kV}$ is 10 $\mathrm{m}$, for $275 \mathrm{kV}$ is $13 \mathrm{~m}$, and for $500 \mathrm{kV}$ is $17 \mathrm{~m}$. PLN itself has made a guardrail to maintain free space and safe distance as well as periodically carry out field strength measurements electricity using electromagnetic tools Field Meters. According to the World Health Organization (WHO) Organization) electric field strength threshold and a magnetic field that does not harm to the human body at $5 \mathrm{kV} / \mathrm{m}$ for the electric field and $0.1 \mathrm{~m}$ Tesla for the magnetic field. From the measurement results of what PLN has done so far, the field strength electricity and magnetism in various areas of SUTT and SUTET in Indonesia are still below the threshold. In addition to periodic measurements, PLN also provides counseling about safe distance rules to society. This training is aimed at giving a correct understanding of the influence of electric and magnetic fields so that people who live around the means of transmission. This have the right perception and sense of security to live in the vicinity. This counseling is usually given by PLN at the beginning of the operation of SUTT and SUTET. Still, this counseling can also be given on another occasion if the community needs it. There has been no agreement from the world health experts on the effects of SUTET on health, including cancer and tumors in children and adults. Because the research is conducted in the whole world, nothing is experimental. Influence causes the movement of electrons to bewilder and causes ionization so new ions and electrons are born. In high-voltage and extra-high voltage cables, because the current flows continuously, the ions and electrons will multiply, especially if the voltage gradient is high enough. Humid air, due to the presence of trees under this extra high voltage transmission, will further accelerate the folding of ions and electrons, which is called an avalanche. As a result of the multiplication of ions and electrons, it will cause a unique phenomenon in SUTET, known as the corona, in the form of a spark or arc of light, which is often accompanied by a hissing sound and a distinctive odor called ozone and does not interfere with health at all

\section{Conclusion}

Based on the results of the discussion, it can be concluded that the influence of wave radiation electromagnetic radiation on human health is still caused a lot of debate and further research is needed, Epidemiological study with a cross-sectional approach. The examination was carried out on 1228 residents, which included a physical examination, blood laboratory, ECG, EEG, as well as an assessment of mental disorders. In this study, it was found that $11 \%$ of respondents experienced abnormalities in the physical examination and $10.2 \%$ of respondents experienced abnormalities in the laboratory. However, the abnormality has no correlation with exposure to electric and magnetic fields originating from the $500 \mathrm{kV}$ SUTET. The electrical sensitivity of residents below $500 \mathrm{kV}$ SUTET is 5.8 times greater than that of residents who do not live under $500 \mathrm{kV}$ SUTET. Electrical sensitivity in this study is a collection of symptoms (syndrome) of hypersensitivity, in the form of complaints of headache (headache), dizziness (dizziness), and chronic fatigue (chronic fatigue syndrome)

\section{References}

1. Anies, SUTET, Potensi Gangguan Kesehatan Akibat Radiasi Elektromagnetik SUTET. Jakarta, PT. Elex Media Komputindo(2006)

2. I.B. Alit Swamardika, Pengaruh Radiasi Gelombang Elektromagnetik Terhadap Kesehatan Manusia Teknik Elektro Fakultas Teknik Universitas Udayana Kampus Bukit Jimbaran, Bali (2009)

3. Akhadi, M., 2016, Dasar-Dasar Proteksi Radiasi, Jakarta: PT Bineka Cipta.

4. Anies. 2016, SUTET, Potensi Gangguan Kesehatan Akibat Radiasi Elektromagnetik SUTET. Jakarta, PT. Elex Media Komputindo.

5. Anies. 2015, Gangguan Kesehatan akibat Radiasi Elektromagnetik. FK Universitas Diponegoro, http://www.kompas.co.id/, diakses 4 Juli 2016

6. Fischetti, M.,1993. The Cellular Phone Scare, IEEE Spectrum. Juni 1993, hal.43

7. Kobb. B.Z.,1993. Personal wireless, IEEE Spectrum. Juni 1993.

8. PT. PLN., 2006. Pembangunan Saluran Udara Tegangan Ekstra Tinggi (SUTET) 500 kV Menjamin Keberlangsungan \& Kehandalan Pasokan Listrik, http://www.pln.co.id/, 2006.

9. Shen, L. C., 1996. Aplikasi Elektromagnetik. Jilid 1 Edisi Ketiga, Erlangga, Jakarta.

10. Silaban Pantur, 2001. Element of Engineering Electromagnetics Fifth Edition. Jilid 1 Edisi Kelima, Erlangga, Jurusan Fisika Institut Teknologi Bandung. 